\title{
Linguistic injustice in academic publishing in English
}

\author{
Limitations and ways forward in the debate
}

\author{
Josep Soler \\ Stockholm University
}

In recent years, an intense debate in English for research publication purposes (ERPP) has developed around the question of whether linguistic injustice exists or not in academic publishing in English. In this Perspectives piece, I wish to engage in this debate by first situating the terms in which it is being developed, and then pointing out some of its limitations. In doing that, I argue that the view of language that is currently held in the debate seems problematic, and that a more explicit attention to the socially stratified nature of academic publishing seems missing from the debate. Suggesting potential ways forward, I propose that it seems crucial to adopt a view of language that anchors it more firmly as a social phenomenon, inherently connected to its speakers and the socially situated and stratified position that they inhabit. Remembering this is important in order to remain aware of the fact that both linguistic and non-linguistic factors are at play in shaping the uneven nature of academic publishing in English.

Keywords: linguistic injustice, academic publishing, English for research publication purposes

\section{Introduction}

In recent years, an intense debate in English for research publication purposes (ERPP) has developed around the question of whether linguistic injustice exists or not in academic publishing in English. In his provocative 2016 article, Hyland argued that L1 background does not constitute a relevant factor in academic publishing in English, and that at best, it should be treated as a contextual variable, less important than, for example, level of expertise. Since both English L1 and English as an additional language (EAL) scholars are affected equally by the linguistic requirements of the genre of writing for publication purposes, Hyland 
holds that linguistic injustice is more a myth than a reality. Such a position has been controversial, and others have responded that language (L1 status in particular) should still be considered as the primary source of the injustice in ERPP (e.g., Flowerdew, 2019; Hanauer et al., 2019; Politzer-Ahles et al., 2016).

In this Perspectives piece, I wish to engage in this debate by first situating the terms in which it is being developed, and then pointing out some of its limitations. In doing that, I argue that the view of language that is currently held in the debate seems problematic, and that a more explicit attention to the socially stratified nature of academic publishing seems missing from the debate. Suggesting potential ways forward, I propose that it seems crucial to adopt a view of language that anchors it more firmly as a social phenomenon, inherently connected to its speakers and the socially situated and stratified position that they inhabit. Remembering this is important in order to remain aware of the fact that both linguistic and non-linguistic factors are at play in shaping the uneven nature of academic publishing in English.

\section{No language-based injustices in academic publishing in English?}

Hyland (2016) suggests that L1 status is not a relevant factor that can account for the injustices in academic publishing in English. In his article, Hyland takes issue with research on EAL authors, noting that its focus on the native-non-native divide is no longer tenable, and that the emphasis on language obscures other important issues of a non-linguistic nature (including level of expertise, access to resources, etc.). In developing his argument, Hyland points to the fact that in ERPP research, a disproportionate attention has gone to analyse the practices, attitudes, and struggles of authors for whom English is an additional language. As a result, English L1 scholars' hurdles in writing for publication purposes have tended to remain underexamined, which has left open a research gap (now partly addressed in e.g., Habibie \& Hyland, 2019), and has made it difficult to assess the extent to which language is or is not a primary obstacle in the publishing process. With the above in mind, Hyland concludes that the existence of linguistic injustice in academic publishing is a myth, and as such, EAL authors do not face languagebased injustices when publishing in English.

In making his case, Hyland builds on previous work (of his own and of others) that shows that EAL scholars do not consider themselves at a disadvantage because of linguistic reasons. Rather, the Hong Kong based informants in his study pointed out training and experience in writing for publication as factors explaining why they actually found it easier to write in English than in Chinese (Hyland, 2016, p.62). Along similar lines, Kuteeva and McGrath (2014) report 
that Swedish scholars in the humanities, particularly those in younger generation groups, might find it more comfortable to produce their work in English than in Swedish, given that the literature they engage is primarily in English. In sum, in the context of the "native speaker" concept having become fuzzier, with more and more "non-native" English-speaking scholars publishing internationally (see also O'Neil, 2018), Hyland (2016) problematizes what he terms the "disadvantage orthodoxy" (p.66), that assumes that EAL scholars are disadvantaged by default in their attempt to publish in English because of linguistic reasons.

In a range of responses, most of them grounded on previously published empirical research, several authors (e.g., Flowerdew, 2019; Hanauer et al., 2019; Politzer-Ahles et al., 2016 and 2020) have found this position far-fetched and have argued the contrary, noting that L1 status should still be of primary concern in ERPP. For Politzer-Ahles et al. (2016), linguistic privilege is well alive in academic publishing in English, with L1 English-speaking scholars enjoying some advantages because of their L1. These advantages include, first, that publishing is easier for them, as they need to spend less time and energy in crafting their texts, and second, that publishing is biased in their favour, as journal editors and reviewers may disproportionately value their work more positively. In a more recent piece, Politzer-Ahles et al. (2020) have tested the second claim further, and have reached the conclusion that readers (i.e., reviewers) tend to be biased against academic English texts that do not conform to international publication standards, even if the content of such texts is valuable (we will return to the issue of reviewers' interpretation of article manuscripts below). Hyland (2020) does note that peer-review is far from perfect, and that subjectivity is unavoidable in the process, but he maintains that "there is little evidence of systematic bias against NNESs" and that "the argument and the need to present the originality and value of the research" (2020, p.55) are more important factors in affecting editors' decisions of acceptance or rejection of manuscripts.

Flowerdew (2019) develops his response to Hyland's (2016) piece focusing on the first of the arguments levelled by Politzer-Ahles et al. (2016): that publishing is easier for L1 English-speaking scholars because they need to spend less time and energy on writing their texts. Flowerdew argues that at the micro-level of text crafting, L1 status can, indeed, make a difference when it comes to mastering key rhetorical features of genre conventions. Flowerdew does concur with Hyland that these specialised forms and uses of the language will need to be learned by all authors, irrespective of their L1, but he adds that "a NS-like command of tense, aspect, voice, and transitivity before coming to these discipline-specific uses is likely to put the L1 writer at an advantage over the EAL writer" (Flowerdew, 2019, p.252). To Flowerdew, the capacity to make faster intuitive judgements on the genre appropriateness of micro-level forms and uses of the language will be greater for L1 English-speaking authors than for EAL writers. 
Bourdieu is often credited with the idea that academic language is no one's first language, that it is a specialised form of the language that needs to be learned, regardless of L1 background. In discussing France's education system, the French sociologist argued that "academic language is a dead language for the majority of French people, and is no one's mother tongue, not even that of children of cultivated classes" (Bourdieu et al., 1994, p.8). However, right after this passage, Bourdieu, Passeron and de Saint Martin add that even if the academic form of the language is no one's $\mathrm{L}_{1}$, "it is very unequally distant from the language actually spoken by the different social classes" (p.8). So, when read in full, the passage provides support to those holding that linguistic privilege does exist to the extent that some "classes" will need to travel a shorter distance than other ones to acquire the specialised jargon. In ERPP terms, linguistic injustice supporters would argue that EAL authors do need to travel a longer distance than their L1 English-speaking colleagues in mastering the genre of writing for academic publishing. The longer distance that EAL scholars need to travel seems well captured by Hanauer et al.s (2019) quantitative data. Indeed, the Mexican and Taiwanese researchers that participated in their study reported higher degrees of difficulty, dissatisfaction, and anxiety when writing for publication purposes in English than in their respective L1.

The above should serve to provide a succinct overview of the main gist of the debate, even if an admittedly rough one, given space. In what follows, I proceed to point out some of the limitations that I detect in it, and I suggest some possible ways to move the discussion forward.

\section{Limitations of the debate and possible ways forward}

The most important limitation that can be detected in the debate, as currently developed, is the conceptualisation of language, and particularly of the specialised English academic literacy forms, that are mobilised by both deniers and defenders of linguistic injustice. Indeed, in both cases, the genre and rhetorical features that are required for successful academic publishing in English are portrayed as a range of resources that exist somewhere in the abstract, independently from their actual speakers/writers; the point of contention is whether or not L1 makes a difference in allowing easier or more difficult access to these resources: yes, it does, linguistic injustice defenders would sustain (e.g., Flowerdew); no, it does not, linguistic injustice deniers would argue (e.g., Hyland). This view of language and academic literacy is close to what Lillis and Curry (2015, p.137; see also Lillis \& Curry, 2010: Chapter 5) have described as "grounded in the Europeanbased Enlightenment tradition of Science and knowledge", where language is seen 
simply as a means of communication, a mere "conduit for meaning". Hyland does insist on the socially situated nature of writing, and he raises the point that "[a]uthorial agency and individual experience, too often ignored in these debates, are key dynamics" (2016, p.66). "What is apparent", Hyland writes, "is that literacy is not a single monolithic accomplishment but a series of socially situated, discipline-sensitive practices that have to be learnt as needed" and that "languages are linguistic practices that have evolved to get things done in particular spheres and not cognitive structures existing inside the head of idealized monolingual Native speakers" (2016, p.67).

Although these arguments certainly do point towards the direction of seeing language as anchored in specific social contexts, an extra step is missing, one that recognises that the "discipline-sensitive [...] linguistic practices" are employed by speakers/writers in the real world, occupying unequal, stratified social positions. To Hyland, these diverse social positions (e.g., different degrees of isolation) affect both English L1 and EAL scholars equally, but they need not be seen in a structurally deterministic way; rather, they should be interpreted as something that can be overcome, presumably (although Hyland does not state that explicitly) by authors' individual agency. Indeed, an over-deterministic interpretation of academic publishing in English runs the risk of removing any degree of agency from speakers/writers; but at the same time, overlooking structural inequalities may paint an overly egalitarian picture that, when applied to language, suggests that once speakers/writers have gained access to and acquired the "right" genre and rhetorical resources, everyone is in the same position to put those resources in use and compete on an equal footing to be seen as a ratified, legitimate participant in the field.

Over the past decade, research within the sociolinguistics of globalisation and mobility (e.g., Blommaert, 2010; Pennycook \& Otsuji, 2015) has underscored the need to conceptualise language as a multiple range of fragmented resources (accents, styles, genres, registers, etc.) that speakers may employ in variable ways depending on their social contexts of interaction. At the same time, however, scholars have also emphasised that speakers' access to those varied resources and their ability to employ them to index specific types of speakerhood or "personae" is socially stratified and unequally distributed. Zooming in to English in particular, May (2015) notes that in the complex centre-periphery relationship of our globalised times (with centres within the periphery and peripheries within the centre), varieties of English that index high social status in one context might not index the same meanings when moved to other contexts in scale shifting trajectories, and that access to English in and of itself does not entail upward social mobility (see also Tupas, 2015). 
Against the background of globalisation forces, when English enters a given academic field, à la Bourdieu, it has the potential to re-arrange the field and the position that social actors take in it, as Salö (2017) has shown. In his work, he documents how humanities scholars in Sweden, particularly junior researchers, may strategically invest in writing in English for publication purposes to situate themselves at an advantage vis-à-vis those who do not make that investment, who typically occupy more senior positions. Salö's argument is important in that he highlights how English can be converted into a form of capital that, together with other resources and not unproblematically (i.e., with an associated risk of destabilising the field), can be mobilised by agents in the right social position to their advantage (Salö, 2017, p.9).

So, English and its specialised genre and rhetorical practices of academic publishing interrelate in complex ways with authors' socially situated positions. In other words, the capacity of authors to carve out an authorial voice for themselves in academic English and to index a sense of legitimacy when publishing in it do not depend simply on their acquisition and use of discipline-specific language practices; rather, both discursive and non-discursive factors are imbricated in complex ways. Intersectionality, then, might be a useful keyword to remind ourselves of the different and simultaneous forms of inequality that run across academic publishing in English. In line with what Lillis and Curry have remarked previously (e.g., 2010), Luisa Martín Rojo (2021, p.174) underscores the need for sociolinguists to continue investigating "how language plays a role as a resource" (emphasis in the original) in constructing and reinforcing inequalities of class, ethnicity, race, gender, language, and social conditions. Martín Rojo (p.174) adds: "Linguistic requirements become an example of intersectionality, where social and economic differences are inseparable from linguistic ones, reinforcing the social stratification of the academic field." Along similar lines, Kubota (2020, p.728) highlights that the stratified nature of academia is permeated by epistemological, individual, and institutional racism, which leads to certain ideas and ways of knowing to be marginalised in favour of other dominant ones:

What we see and hear in books, journals, or conferences are the results of the decisions to accept or reject certain ideas produced by real people. These decisions made by authors, presenters, reviewers, and editors affect how many male or female scholars or white, black, indigenous, Asian, and Latinx scholars appear in publication titles and conference programs.

From this perspective, language is a key resource that rests at the centre of social inequalities in academia. Both Kubota and Martín Rojo's arguments point incisively to the fact that injustice in academic publishing cannot be detached from the broader inequalities in academia, punctured by neoliberal and late capitalist 
structures of inequality. Recent work in applied linguistics has underscored the need to incorporate concepts and methodologies of political economy more decidedly than traditionally done, precisely with the goal of flagging more prominently how socio-economic inequalities interrelate and are co-constituted by sociolinguistic ones (e.g., Block, 2018; Holborow, 2015; Martín Rojo \& Del Percio, 2020). So, to the extent that the central channels of academic production and dissemination continue to be built around Anglo-American structures (e.g., key journals, learned societies and associations, conferences, etc.) that operate in a specialised form of English that is validated in largely inaccessible social spaces (via high conference fees and journal subscriptions), many scholars that come from other sociolinguistic, cultural, and geographical positions will continue to face bigger challenges in order to join their discourse communities of reference and to be seen as legitimate participants in them. This will be particularly the case for those socialised in genre and rhetorical conventions of other academic traditions. First as outsiders, those scholars will need to put the conventions they are more familiar with to one side, as they progressively develop a voice for themselves in the Anglo-American tradition of their field; but, in doing that, they will be more vulnerable to critique, and perhaps marginalisation, by those who see themselves as already members of the reference discourse community (DołowyRybińska, 2021).

The tensions inherent in developing an authorial voice are perhaps clearest in the peer-review process of academic publishing. Importantly, at that stage, it is not only the writers' skills to employ the "right" genre and rhetorical conventions that play a role, but also the readers' (and particularly reviewers' and editors') interpretation of them. As Matsuda and Tardy (2007, p. 246) note, readers attend to marked discursive features (e.g., inconsistent style, lack of concision) that can reveal nondiscursive characteristics of writers (e.g., race or gender). So, it is "in the readers' eyes" (p.246, emphasis in the original) that the marked nature of the discursive and non-discursive features becomes alive (see also Tardy \& Matsuda, 2009). For those less familiar with the rhetorical conventions of academic English, this is a crucial aspect. If the "odd" features of English that the reader identifies in the manuscript are construed as problematic and need "fixing" or "polishing", these perceptions may likely influence editors' overall evaluations of the manuscript (Lillis \& Curry, 2015, p.141). While a cause-effect relationship between "unusual features" and rejection of an article cannot be established, Lillis and Curry (2015) show that when reviewers construe "English" or "language" as problematic, these representations add to the overall rationale for rejection by the editor.

So, in bringing our debates about injustice in academic publishing in English forward, it might be useful to turn our focus of attention from writers to readers, or more specifically from "writing-subject" to "reading-subject" positions. In edu- 
cational linguistics, a discussion has developed over the last few years that focuses on the "listening subject", flagging the idea that members of racialised minority populations in the US, despite empirical evidence of their ability to engage in standard forms of English correctly, continue to be positioned as structurally marginalised by the "white listening subject" (Flores \& Rosa, 2015). Extrapolating this argument into ERPP, one could argue that even if EAL authors show appropriate mastery of the "acceptable" writing conventions to have their work published in English, a degree of resistance to EAL texts and voices will remain by virtue of how the system is structured.

In that line, Corcoran (2017) shows that courses designed to support scholars working in peripheral institutional settings (in the case of his study, Mexico) are not enough to assist them in publishing, suggesting that access to the "correct" standardised forms of English for publication purposes may not be sufficient to grant certain demographics the capacity to get their work published and to be seen as legitimate participants in the scholarly conversations they aim to enter. Hyland (2016) conjectures that the more frequently non-standard forms of English appear in published texts, the more they will gain acceptance and validity. He refers to Rozycki and Johnson (2013), who find that simplified grammar was widely used in prize-winning articles by non-native English-speaking authors in prestigious engineering journals. However, aside from a disciplinary effect, it may also be possible to suggest that there are some (those who stand to win prizes in their field) who can afford the possibility of a widespread use of simplified grammar without much risk at all, while others remain far from enjoying those benefits. A study by McKinley and Rose (2018) shows that journal submission guidelines are rather inflexible in accepting non-conforming uses of English, positioning L2 users of the language as deficient of native standards (see also Heng Hartse \& Kubota, 2014); so, EAL authors do seem to stand in a vulnerable position to have their English "oddities" construed negatively.

\section{Concluding remarks}

In this Perspectives piece, I have tried to engage with the linguistic injustice debate in academic publishing in English. I have summarised briefly the arguments of the two sides of the debate since Hyland (2016) provocatively classified linguistic injustice in academic publishing as a myth, and I have suggested some of the limitations of the debate, namely: (1) a generally problematic conceptualisation of language, and (2) an insufficient attention of the socially stratified nature of academic publishing. In developing these limitations further, I have argued in favour of a more explicit political-economic orientation to the question of injustice in acad- 
emic publishing, embedded and inseparable from the broader inequalities in the current neoliberal academia. From this angle, both language and non-linguistic factors intersect in complex forms and may give way to injustice and inequality in specific socially-situated contexts.

The centrality of both discursive and non-discursive factors has long been present in the debates on inequality in academic publishing (cf., Canagarajah, 1996), but I would suggest we run the risk of overlooking the double-sided dimension of the debate if we insist on discussing whether language is or is not a (primary) source of injustice in academic publishing. Flagging language as a main source of injustice, or unflagging language in favour of other non-discursive factors, might be counterproductive. As Hultgren (2019) reminds us, we should be cautious of interpretations that over-emphasise language as the primary cause of injustice in academic publishing, acting in this way as a "red herring" that distracts from other factors of inequality, primarily of socio-economic nature. In proposing ways forward, I have suggested that intersectionality and an attention to readers' construction of authors' voices seem productive routes to continue digging further into how language works not in isolation or even as a main factor of injustice, but as a key resource where different axes of inequality intersect and may lead to injustices for real speakers/writers in real contexts.

In conclusion, the debate on linguistic injustice in academic publishing in English is a complex one, which cannot be easily discerned as a matter of binary opposites (English L1 vs. EAL scholars, novice vs. expert ones, etc.). At a time when English has spread so widely as a language of international communication, when scholars who use it as a second or other language outnumber those whose L1 is English (O'Neil, 2018), it seems tempting to suggest that L1 status has no bearing on shaping the injustices in academic publishing. However, as I have tried to argue above, language (conceived firmly as a social phenomenon) plays a crucial role at that, and we will need to continue monitoring the intricate interplay between discursive and non-discursive factors in socially situated contexts, analysing how speakers/writers in those contexts mobilise their variably available resources the best they can to achieve their goals. These contextualised analyses will allow us to unpack and better understand the factors that enable or constrain the linguistic choices of speakers in socially situated spaces, and the consequences of these choices. Perhaps from that stance, we might be in a better position to imagine ways that can enhance a more equitable and democratic participation in the global production and dissemination of knowledge.

\section{Funding}

Open Access publication of this article was funded through a Transformative Agreement with Stockholm University. 


\section{Acknowledgements}

I would like to express my sincere gratitude to the two anonymous reviewers who provided comments to an earlier version of this article. Their points and suggestions were of extreme help in clarifying the focus of the text and the development of its main arguments. In addition, the revisions of the manuscript coincided with my participation at a NOS-HS workshop on "Translocality, translingualism and multilingual writing", hosted by the Department of English at Stockholm University, 27-28 May 2021. The discussions during the workshop had a significant influence on my thinking about the topic of injustice in academic writing, so I would like to acknowledge the impact of all the presentations and the discussions by all participants. Any remaining shortcomings in the article are, of course, only my own.

\section{References}

Block, D. (2018). Political economy and sociolinguistics: Neoliberalism, inequality and social class. Bloomsbury.

Blommaert, J. (2010). The sociolinguistics of globalization. Cambridge University Press. https://doi.org/10.1017/CBO9780511845307

Bourdieu, P., Passeron, J.C., \& De Saint Martin, M. (1994). Academic discourse, linguistic misunderstanding, and professorial power. Stanford University Press.

Canagarajah, A.S. (1996). "Nondiscursive" requirements in academic publishing, material resources of periphery scholars, and the politics of knowledge production. Written Communication, 13(4), 435-472. https://doi.org/10.1177/0741088396013004001

Corcoran, J. (2017). The potential and limitations of an English for research publication purposes course for Mexican scholars. In M. J. Curry \& T. Lillis (Eds.), Global academic publishing: Policies, perspectives and pedagogies (pp. 233-248). Multilingual Matters. https://doi.org/10.21832/9781783099245-021

Dołowy-Rybińska, N. (2021). Publishing policy: Toward counterbalancing inequalities in academia. International Journal of the Sociology of Language, 267-268, 99-104. https://doi.org/10.1515/ijsl-2020-0090

Flores, N., \& Rosa, J. (2015). Undoing appropriateness: Raciolinguistic ideologies and language diversity in education. Harvard Educational Review, 85(2), 149-171. https://doi.org/10.17763/0017-8055.85.2.149

Flowerdew, J. (2019). The linguistic disadvantage of scholars who write in English as an additional language: Myth or reality. Language Teaching, 52, 249-260. https://doi.org/10.1017/So261444819000041

Habibie, P., \& Hyland, K. (Eds.) (2019). Novice writers and scholarly publication. Authors, mentors, gatekeepers. Palgrave Macmillan. https://doi.org/10.1007/978-3-319-95333-5

Hanauer, D., Sheridan, C., \& Englander, K. (2019). Linguistic injustice in the writing of research articles in English as a second language: Data from Taiwanese and Mexican researchers. Written Communication, 36, 136-154. https://doi.org/10.1177/0741088318804821

Heng Hartse, J., \& Kubota, R. (2014). Pluralizing English? Variation in high-stakes academic texts and challenges of copyediting. Journal of Second Language Writing, 24, 71-82. https://doi.org/10.1016/j.jslw.2014.04.001 
Holborow, M. (2015). Language and neoliberalism. Routledge. https://doi.org/10.4324/9781315718163

Hultgren, A. K. (2019). English as the language for academic publication: On equity, disadvantage and "non-nativeness" as a red herring. Publications, 7, 31. https://doi.org/10.3390/publications7020031

Hyland, K. (2016). Academic publishing and the myth of linguistic injustice. Journal of Second Language Writing, 31, 58-69. https://doi.org/10.1016/j.jslw.2016.01.005

Hyland, K. (2020). Peer review. Objective screening or wishful thinking? Journal of English for Research Publication Purposes, 1(1), 51-65. https://doi.org/10.1075/jerpp.19010.hyl

Kubota, R. (2020). Confronting epistemological racism, decolonizing scholarly knowledge: Race and gender in applied linguistics. Applied Linguistics, 41(5), 712-732. https://doi.org/10.1093/applin/amzo33

Kuteeva, M., \& McGrath, L. (2014). Taming Tyrannosaurus Rex: English use in the research and publication practices of humanities scholars in Sweden. Multilingua, 33(3-4), 365-387. https://doi.org/10.1515/multi-2014-0017

Lillis, T., \& Curry, M.J. (2010). Academic writing in a global context. The politics and practices of publishing in English. Routledge.

Lillis, T., \& Curry, M. J. (2015). The politics of English, language and uptake. The case of international academic journal article reviews. AILA Review, 28, 127-150. https://doi.org/10.1075/aila.28.06lil

Martín Rojo, L. (2021). Hegemonies and inequalities in academia. International Journal of the Sociology of Language, 267-268, 169-192. https://doi.org/10.1515/ijsl-2020-0077

Martín Rojo, L., \& Del Percio, A. (Eds.) (2020). Language and neoliberal governmentality. Routledge.

Matsuda, P.K., \& Tardy, C.M. (2007). Voice in academic writing: The rhetorical construction of author identity in blind manuscript review. English for Specific Purposes, 26, 235-249. https://doi.org/10.1016/j.esp.2006.10.001

May, S. (2015). The problem with English(es) and linguistic (in)justice. Addressing the limits of liberal egalitarian accounts of language. Critical Review of International Social and Political Philosophy, 18(2), 131-148. https://doi.org/10.1080/13698230.2015.1023629

McKinley, J., \& Rose, H. (2018). Conceptualizations of language errors, standards, norms and nativeness in English for research publication purposes: An analysis of journal submission guidelines. Journal of Second Language Writing, 42, 1-11. https://doi.org/10.1016/j.jslw.2018.07.003

O’Neil, D. (2018). English as the lingua franca of international publishing. World Englishes, 37 (2), 146-165. https://doi.org/10.1111/weng.12293

Pennycook, A., \& Otsuji, E. (2015). Metrolingualism. Language in the city. Routledge. https://doi.org/10.4324/9781315724225

Politzer-Ahles, S., Holliday, J.J., Girolamo, T., Spychalska, M., \& Berkson, K.H. (2016). Is linguistic injustice a myth? A response to Hyland (2016). Journal of Second Language Writing, 34, 3-8. https://doi.org/10.1016/j.jslw.2016.09.003

Politzer-Ahles, S., Girolamo, T., \& Ghali, S. (2020). Preliminary evidence of linguistic bias in academic reviewing. Journal of English for Academic Purposes, 47. https://doi.org/10.1016/j.jeap.2020.100895

Rozycki, W., \& Johnson, N.H. (2013). Non-canonical grammar in best paper award winners in engineering. English for Specific Purposes, 32, 157-169.

https://doi.org/10.1016/j.esp.2013.04.002 
Salö, L. (2017). The sociolinguistics of academic publishing. Languages and the practices of homo academicus. Palgrave Macmillan. https://doi.org/10.1007/978-3-319-58940-4

Tardy, C. M., \& Matsuda, P.K. (2009). The construction of author voice by editorial board members. Written Communication, 26(1), 32-52. https://doi.org/10.1177/0741088308327269

Tupas, R. (Ed.) (2015). Unequal Englishes: The politics of Englishes today. Palgrave Macmillan. https://doi.org/10.1057/9781137461223

\section{Injustícia lingüística en anglès per a publicacions acadèmiques: Límits i passos endavant en el debat}

\section{Resumen}

En els darrers anys, hi ha hagut un debat intens en el camp de l'anglès per a publicacions acadèmiques en relació amb l'existència o no d'injustícia lingüística a l'hora de publicar en anglès. En aquesta nota de la secció Perspectives, miro d'entrar en aquest debat, primerament, situant-ne els termes en què es desenvolupa, i després assenyalant-ne alguns límits. Largument que desenvolupo és que el concepte de llengua que es manté en el debat sembla problemàtic i que una atenció més explícita a l'estratificació social del camp de les publicacions acadèmiques sembla absent en el debat. Suggerint passos endavant, proposo que sembla crucial adoptar una visió de llengua que estigui fermament emmarcada com a fenomen social, inherentment connectada als parlants i a les posicions socialment estratificades que habiten. Recordar això és important per continuar estant atents al fet que tant factors lingüístics com factors no-lingüístics juguen un paper a l'hora de donar forma a la naturalesa desigual de l'anglès per a publicacions acadèmiques.

\section{Address for correspondence}

\section{Josep Soler}

Stockholm University

Department of English (room E806)

SE-10691 Stockholm

Sweden

josep.soler@english.su.se

\section{Publication history}

Date received: 26 February 2021

Date accepted: 28 June 2021

Published online: 10 January 2022

Corrected: 13 January 2022 